\title{
Influence of the Heat Treatment on Corrosion Behaviour and Mechanical Properties of the AA 7075 Alloy
}

Vojtěch Kučera, Dalibor Vojtěch

Department of Metals and Corrosion Engineering, University of chemistry and technology Prague, Technická 5, 16628 Prague 6, Czech Republic. E-mail: kucerao@vscht.cz

\begin{abstract}
$\mathrm{Al}-\mathrm{Zn}-\mathrm{Mg}-\mathrm{Cu}$ alloys possess excellent mechanical properties, and therefore are used in aerospace and automotive industry. However, they are susceptible to localized corrosion such as pitting, intergranular and exfoliation corrosion, which is closely related to the precipitate size and distribution. Because the size and distribution of the precipitates are controlled by heat treatment, we investigated the influence of the heat treatment on corrosion behaviour and mechanical properties of the AA 7075 alloy. Audi test, internal Audi standard PV 1113 for automotive industry, was chosen to evaluate the corrosion behaviour of the as-cast, T5 and T6 heat treated aluminium alloy 7075. Mechanical properties were studied through the tensile test and hardness measurements. The highest corrosion rate and the depth of corrosion attack penetration were observed for the T5 state, while the T6 state evinced the best resistance to localized corrosion and the highest mechanical properties.
\end{abstract}

Keywords: AA 7075, Intergranular corrosion, Exfoliation, Heat treatment, Audi test

\section{Acknowledgement}

The authors wish to thank the Czech Science Foundation (project no. P108/12/G043) for its financial support of this research.

\section{References}

[1] JIANG, D., et al. (2016). The effects of non-isothermal aging on the strength and corrosion behavior of AlZnMgCu alloy. In: Journal of Alloys and Compounds, Vol. 681, No., pp. 57-65.

[2] HUGHES, A.E., et al. (2011). High Strength Al-Alloys: Microstructure, Corrosion and Principles of Protection. Recent Trends in Processing and Degradation of Aluminium Alloys; Available from: https://www.intechopen.com/books/recent-trends-in-processing-and-degradation-of-aluminium-alloys/high-strength-al-alloysmicrostructure-corrosion-and-principles-of-protection.

[3] LI, B., et al. (2016). Effect of aging time on precipitation behavior, mechanical and corrosion properties of a novel Al-Zn-Mg-Sc-Zr alloy. In: Transactions of Nonferrous Metals Society of China, Vol. 26, No. 9, pp. 2263-2275.

[4] LUŠTINEC, J., OČENÁŠEK V., JELÍNEK JR:, M. (2016). Structure of Al-Mg-Si Cast and Extruded Rods for Die Forgings In: Manufacturing Technology, Vol. 16, No. 5, pp. 1009 - 1013.

[5] LAGO, J., et al. (2016). Qualitative Evaluations of the AlSi7Mg0.3 Microstructure by the X-Ray Diffractometry. In: Manufacturing Technology, Vol. 16, No. 6, pp. $1284-1291$.

[6] JASIM M. SALMAN, S.A.A.A., K. F. Al-SULTANI. (2013). Improvement Properties of 7075-T6 Aluminum Alloy by Quenching in 30\% Polyethylene Glycol and Addition 0.1\%B. In: Research Journal of Material Sciences, Vol. 1, No. 6, pp. $12-17$.

[7] MAITRA, S.,G.C. ENGLISH. (1982). Environmental factors affecting localized corrosion of 7075-t7351 aluminum alloy plate. In: Metallurgical Transactions A, Vol. 13, No. 1, pp. 161-166.

[8] RAO, A.C.U., et al. (2016). Stress corrosion cracking behaviour of 7xxx aluminum alloys: A literature review. In: Transactions of Nonferrous Metals Society of China, Vol. 26, No. 6, pp. 1447-1471.

[9] SU, R.-M., Y.-D. QU, R.-D. LI. (2014). Effect of Aging Treatments on the Mechanical and Corrosive Behaviors of Spray-Formed 7075 Alloy. In: Journal of Materials Engineering and Performance, Vol. 23, No. 11, pp. 38423848.

[10] WEI, L.L., et al. (2015). Effect of aging on corrosion property, electrochemical behavior and microstructure of Al$\mathrm{Zn-Mg-Cu}$ alloy. In: Materials and Corrosion, Vol. 66, No. 1, pp. 54-60.

[11] KUMAR, P.V., G.M. REDDY, K.S. RAO. (2015). Microstructure, mechanical and corrosion behavior of high strength AA7075 aluminium alloy friction stir welds - Effect of post weld heat treatment. In: Defence Technology, Vol. 11, No. 4, pp. 362-369. 
[12] WEISS, V., SVOBODOVÁ, J. (2015). The use of colour metallography and EDS for identification of chemical heterogeneity of selected aluminium alloys copper and zinc alloyed. In: Manufacturing Technology, Vol. 15, No. 6, pp. $1048-1053$.

[13] ROMETSCH, P.A., Y. ZHANG, S. KNIGHT. (2014). Heat treatment of 7xxx series aluminium alloys-Some recent developments. In: Transactions of Nonferrous Metals Society of China, Vol. 24, No. 7, pp. 2003-2017.

[14] JABBARI TALEGHANI, M.A., E.M. RUIZ NAVAS, J.M. TORRALBA. (2014). Microstructural and mechanical characterisation of 7075 aluminium alloy consolidated from a premixed powder by cold compaction and hot extrusion. In: Materials \& Design, Vol. 55, No., pp. 674-682.

[15] TASH, M.M.,S. ALKAHTANI. (2015). Aging and Mechanical Behavior of Be-Treated 7075 Aluminum Alloys. In: Aging, Vol. 1, No., pp. 7395.

[16] El-AMOUSH, A.S. (2011). Intergranular corrosion behavior of the 7075-T6 aluminum alloy under different annealing conditions. In: Materials Chemistry and Physics, Vol. 126, No. 3, pp. 607-613. 